\title{
Reflections surrounding the identification of the virus HTLV- 1 in DNA samples from prehispanic populations from northern Chile
}

\author{
Lautaro Núñez A. ${ }^{1}$, Calogero M. Santoro ${ }^{2}$, Vivien G. Standen ${ }^{2}$ and Francisco Téllez ${ }^{1}$
}

\section{RESUMEN}

Una secuencia cronológica, cultural y bioantropológica de cuerpos momificados y restos esqueletarios de los valles occidentales de Anca y del territorio circumpuneño de San Pedro de Atacama se presenta en términos de comprender el proceso adaptativo e intracultural a nivel regional, y sus relaciones con los territorios fronterizos.

En este contexto, la evidencia de Human T-Cell Leukemia Virus Type (HTLV-1) recurrente entre la población japonesa actual y del área estudiada se ha evaluado a través de los remanentes étnicos andinos. Ahora se presentan muestras obtenidas de cuerpos humanos prehispánicos, los cuales fueron analizados con aplicaciones multidisciplinarias con resultados positivos, confirmando la extensión de un paleovirus extraamericano en el área centro sur andina. La identificación de HTLV- 1 entre poblaciones prehispánicas se ha datado entre los 900 a los 1.200 años d.C. al interior del radio de influencia del estado altiplánico Tiwanaku, a través de poblaciones emplazadas en el suroeste del mundo andino.

El análisis arqueológico permite interpretar estos datos en términos de reactivar la cuestión de los orígenes del poblamiento americano, enfatizando el rol de los componentes protoasiáticos, arribados por distintas vías hacia Sudamérica, con marcadores biológicos presentes en sociedades complejas del área centro sur andina.

\section{INTRODUCTION}

This work has as its objective the discussion, from an

1 Instituto de Investigaciones Arqueológicas y Museo, Universidad Católica del Norte, San Pedro de Atacama, Chile.

2 Departamento de Arqueología y Museología, Universidad de Tarapacá, Arica, Chile. anthropological point of view, of the results of the paleoepidemiological studies carried out by the Japanese-Chilean scientific mission directed by K. Tajima, S. Sonoda and L. Cartier. The analyses permitted the isolation and amplification of the genes of the virus HTLV- $1, \beta$ globin and HLADQB 1 preserved in DNA segments obtained from bone marrow and mummified human remains from northern Chile, $17^{\circ}$ to $19^{\circ}$ south latitude. The virus HTLV-1, related to the transmission and manifestation of leukemia, has a worldwide distribution among local ethnic groups located in relatively isolated territories (Tajima, 1996). Five samples of ancient DNA from a total of 119 individuals ( 77 from Arica and 42 from San Pedro de Atacama) show positive results, confirming the existence of these genetic factors in relatively isolated pre-Hispanic ethnic groups in northern Chile. The paleoepidemiological analyses also include samples from contemporary native populations in Japan and Chile, demonstrating in both groups a high incidence of the virus HTLV-1. The Chilean examples from the localities of Toconao and San Pedro de Atacama in the Salar de Atacama (Figure 1), have the highest frequency of positive cases of HTLV- 1, at $12.3 \%$, consistent with the highest reponed indices in Southwestern Japan, where they reach 13\% (Hong-Chuan et al., 1998a ms; Tajima, 1996). For the methodological and theoretical descriptions of the paleoepidemiological studies commented in this paper please refer to other works in this volume. Our purpose here is to analyze the cultural implications of the results of these studies.

The paleoepidemiological study of this virus can shed light on the routes of human colonization of isolated regions such as Australia, South America and the Japanese archipelago. The virus is transmitted from mother to child through lactation or from man to woman through sexual contact and tends to have a lower incidence in more geographically and/ or socially open communities.

By contrast, geographic and/or social (for example, endogamy) isolation can produce an 
increase in frequency. Thus the virus can easily disappear in a few generations if the carrying population comes into contact with noncarriers.

The field of paleoepidemiology is a complementary field to anthropology (Ikeda and Yoshida, 1996). The identification of this genetic indicator in pre-Hispanic populations of northern Chile, for example, opens up an independent line of evidence concerning the antiquity and distribution of the migratory pathways to South America in general and to northern Chile in particular. In addition, it can aid in a more precise identification of the origin and characteristics of the ancestral populations. The data enriches the discussion surrounding the biological and cultural evolution of the populations that inhabited the macro-region of northern Chile. It may also shed light on the degree of isolation of the population and kinship patterns.

\section{Material}

\section{The study area}

The territory of northern Chile between the latitudes of 17 and 19 degrees south is characterized by a hyperarid climate along the coast and the intermediate zone, between the littoral and the Andean highlands (Figure 1). In the Andean highlands, above 3,000 meters of elevation above sea level, there is an equally important north-south latitudinal gradient of increasing aridity. The scarcity of surface water creates landscapes characterized by deep ravines that descend gently from the western slope of the Andes, with intermittent streams courses forming oases, complemented by springs throughout the length of the ravines. These ravines and oases constitute true islands in the northem Chilean desert, separated by totally arid, interfiuvial pampas.

Consequently, the highlands to the east, the ocean to the west, and the absolute desert to the south of the Loa basin define a geographically isolated territory, a zone peripheral to the evolution of civilization in the highland of central Bolivia. Moreover, within this macro territory, with an area ca $800 \mathrm{~km}$ long and 200 to $250 \mathrm{~km}$ wide, there are important ecological barriers (deep valleys and interfluvial desert pampas), which inhibited interaction between populations during the preHispanic period. On a biological level, these barriers provoked specialization among plant and animal species found today throughout this mosaic territory (Veloso and Bustos, 1982).
Did these ecological conditions favor the transmission and perpetuation of the HTLV- 1 virus in the local populations beginning around 2,000 years ago? The interpretation of the culture history emphasized that the geographic barriers did not limit social and cultural interaction between settlements within and surrounding the macro region. It has been suggested that the development of the agriculturalpastoral communities was in part due to the great ability of these settlements-communities to integrate resources of the most diverse ecological levels through a dynamic mechanism of regional integration based on high mobility manifested through caravan routes, geoglyphs, petroglyphs and interzonal traffic (Núñez and Dillehay, 1978). Ferrel et al. (1982) identified a mutant of the enzyme eritrocitaria fosfoglucomatosa 1 , a factor with a low frequency in human populations (only 2 gametes per million produce viable individuals). When one of them is identified in widely separated populations, it indicates that these populations shared kinship ties. This mutant has been identified among Aymaran and Atacaman populations, as well as among the Macushi and Wayampi tribes of the Brazilian Amazon rainforest. These results imply miscegenation of populations throughout the millennia. The biological contacts between populations, however, can be produced by diverse processes of social interrelation, including parties of warriors assaulting neighboring communities in search of wives.

\section{Paleoepidemiology and cultural history}

Our purpose is to place these paleoepidemiological results in a prehistoric context regarding Andean populations in northern Chile, concentrating on their lifestyles and social organization that could explain, in part, the presence of this genetic trait. Taking into account the high incidence of these genetic factors in the natives of Japan, we also discuss possible pathways of migration and colonization from Asia to South America and their respective time periods.

\section{Analyzed samples}

The Japanese-Chilean paleoepidemiological project collected 119 samples from pre-Hispanic populations: 77 from Arica and 42 from San Pedro de Atacama. The specimens from Arica (Figure 1) represent individuals in 13 cemeteries that encompass a chronological range from the Formative Period to the Late Period, related to the period of the Inka 


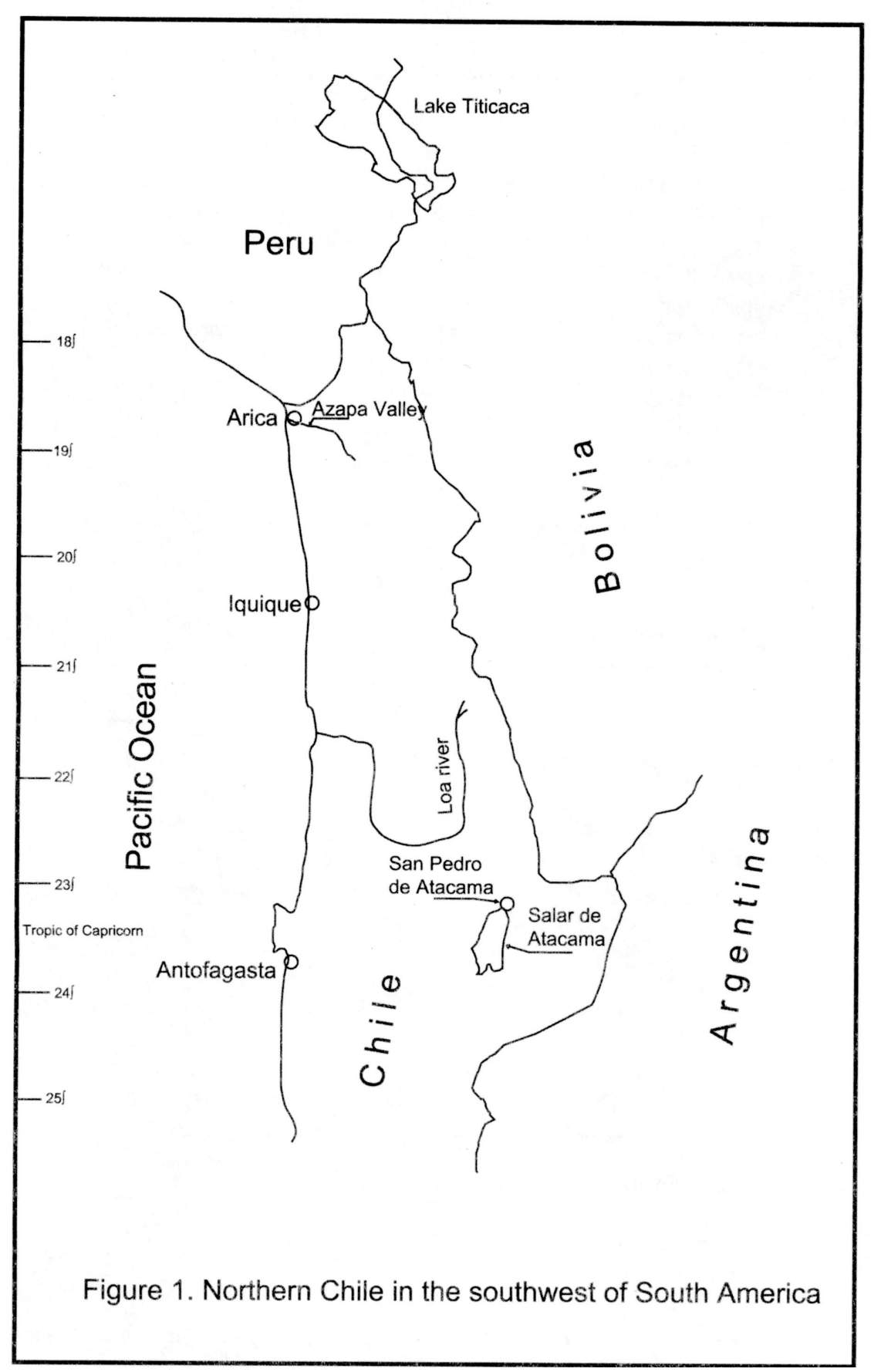

Empire (1,000 BC. - AD 1,500; see Table 1). Samples from earlier hunting and gathering populations were not included in this study.

The samples from Salar de Atacama (Figure 1) were collected from agricultural-ceramic period populations that encompass a range from between $400 \mathrm{BC}$ and $\mathrm{AD}$ 1,400. Sites, location, cultural period, and chronology are listed in Table 2.

\section{Results}

From the Arica samples, only one case was positive for the HLA-DQB $1 * 0502$. This sample, consisting of muscle, marrow, and bone, was obtained from site AZ-71, tomb 602, which belonged to an adult male, about 55-60 years old. Of the samples from San Pedro de Atacama, the sample SP-2 (I),corresponding 


\begin{tabular}{llll}
\hline Site & Location & Period & Chronology \\
\hline AZ-75 & Azapa Valley & Formative Period & 1,000 BC - AD 400 \\
PL.M-6 & Coast of Arica & Middle Horizon & AD 400-1,000 \\
AZ-6 & Azapa Valley & Middle Horizon & AD 400-1,000 \\
AZ-71 & Azapa Valley & Middle Horizon & AD 400-1,000 \\
AZ-75 & Azapa Valley & Middle Horizon & AD 400-1,000 \\
AZ-140 & Azapa Valley & Middle Horizon & AD 400-1,000 \\
AZ-141 & Azapa Valley & Middle Horizon & AD 400-1,000 \\
CAM-8 & Coast of Camarones Valley & Late Intermediate & AD 1,000-1,400 \\
CAM-9 & Coast of Camarones Valley & Late Intermediate & AD 1,000-1,400 \\
PL.M-3 & Coast of Arica & Late Intermediate & AD 1,000-1,400 \\
PL.M-9 & Coast of Arica & Late Intermediate & AD 1,000-1,400 \\
AZ-11 & AzapaValley & Late Intermediate & AD 1,000-1,400 \\
AZ-75 & Azapa Valley & Late Intermediate & AD 1,000-1,400 \\
\hline
\end{tabular}

Table 1. Samples from prehistoric cemeteries of Arica.

\begin{tabular}{|c|c|c|c|}
\hline Site & Location & Period & Chronology \\
\hline $\begin{array}{l}\text { CASA PARROQUIAL } \\
\quad(C S P)\end{array}$ & San Pedro de Atacama & Middle Horizon & $400-1000 \mathrm{AD}$ \\
\hline $\begin{array}{l}\text { COYO ORIENTE } \\
\quad(\text { CyOr })\end{array}$ & San Pedro de Atacama & Middle Horizon & $400-1000 \mathrm{AD}$ \\
\hline $\begin{array}{l}\text { QUTTOR } 6 \\
\quad(\text { Qt.6) }\end{array}$ & San Pedro de Atacama & Middle Horizon & $400-1000 \mathrm{AD}$ \\
\hline $\begin{array}{c}\text { QUITOR } 2 \\
(\text { Qt.2) }\end{array}$ & San Pedro de Atacama & Middle Honizon & $400-1000 \mathrm{AD}$ \\
\hline $\begin{array}{l}\text { SOLOR } 3 \\
(\text { Sl.3) }\end{array}$ & San Pedro de Atacama & Late Intermediste & $1000-1400 \mathrm{AD}$ \\
\hline $\begin{array}{r}\text { QUITOR } \\
\text { (Qt.1) }\end{array}$ & San Pedro de Atacama & Late Intermediste & $1000-1400 \mathrm{AD}$ \\
\hline
\end{tabular}

Table 2. Samples from prehistoric cemeteries of San Pedro de Atacama.

to the Casa Parroquial site (Tellez, 1997, ms), showed positive results for factors HTLV-1 px and $\beta$-globin. Sample SP-li, from the same site, was positive for the factor P-globin. The most important finding was the identification of the HTLV-1

1 These dates were processed thanks to the kindness of Dr. Gray Graffan, visiting investigator from the Instituto de Investigaciones Arqueológicas y Museo, Universidad Católica del Norte. factor from Casa Parroquial (Hong-Chuan, 1998b, ms), dating between AD 370 (Beta-941 13) andAD 800 (Beta-94 114)'. The presence of portrait vessels and kero vessels embossed and laminated in gold place the cemeteries in the middle of the Tiwanaku period. This trait shows a clear connection to the nuclear region of Tiwanaku in the central Bolivian highland. In addition, in $45 \%$ of the tombs, individuals possess evidence of social hierarchy in the form of ornamental pieces of gold, silver and copper (Tellez, 1997, ms). 
We do not know with certainty if the population of Casa Parroquial is of local origin or if it corresponds to a colony originated in the highland. Perhaps Casa Parroquial existed as an elite group installed by the Tiwanaku state to carry out the mining-metallurgic production at the Salar de Atacama (see discussion in Oakland-Rodman 1992). If this was the case, evidence of these socially differentiated groups should be found in local villages, with access to prestige goods and distinctive architecture. However, villages of this era do not contain Tiwanaku-style ceramics, such as have been identified in the residential complex of Coyo, although the investigation of Coyo village archaeological deposits is still in its initial stages and cannot be proven conclusive.

For this reason, we are inclined to think that the population of Casa Parroquial corresponds to leaders of local origin, who may or may not constitute lineages with consanguinial ties of kinship and who based their prestige on the possession of exotic goods (metal objects of Tiwanaku origin). The presence of miniature gold objects in tombs of children (i.e. Casa Parroquial, T-16) coud indicate certain incipient levels of socially ascribed or inherited power among the local population. This implies that the presence of Tiwanaku in the oasis of San Pedro de Atacama can be attributed to the interaction between local leaders and the centers of power in the Bolivian highland, rather than by colonization from the north of the territory.

If so, the appearance of the marker HTLV- 1 could be a consequence of the natural isolation that characterizes this hyper-arid desert region, since the cultural sequence from the Archaic and Formative periods to the Tiwanaku Period does not exhibit a hiatus or substantial cultural discontinuities. If this scenario is correct, it can be suggested that this marker was transported during the first migrations of hunter-gatherers around 10,000 years BP.

This alternative can be evaluated by analyses of pre-formative populations, either archaic or paleoIndian. If the factor appears in these precursor populations, the hypothesis of an early entry and a process of relative biological isolation would be supported. If, on the contrary, it were found that this factor was absent in early population studies should be conducted in Middle Period sites of the Titicaca region. It's presence there would indicate that factors entered northern Chile along with the cultural expansion of the Andean nuclei of power, first
Tiwanaku, followed by Aymara and Quechua populations.

This pattern of biological continuity in a context of relative geographic isolation is repeated in Japan, manifested in the high incidence of the factor HTLV1. In the Japanese archipelago, however, there are two subgroups of HTLV-1: «A» and «B». Group «B» is not present in South America (Ido, Yamashita, and Hayami, 1996). The genetic component «A» could have entered with the first migrations that colonized Japan from Asia beginning 10,000 years BP, identified as preagricultural Jomon (Ido, Yamashita, and Hayami, 1996:111). The factor «B» would have entered Japan after 10,000 years BP subsequent to the disappearance of the Bering isthmus, thus impeding migrations into the Americas. This could explain the absence of HTLV- 1 «B» in the new world (Ido, Yamashita, and Hayami, 1996).

On its own, HTLV- 1 «A» managed to form its first phylogenetic group in Japan which implies a long temporal trajectory. This favors the hypothesis of an early introduction of this factor coinciding with the oldest migrations. The alternative explanation, which would reactivate the hypothesis of trans-Pacific migrations (Meggers, 1998), is a later introduction to South America across the Pacific Ocean. Gonçalvez de Araujo (1987) presents paleoparasitological evidence in the form of coprolites, from populations of Piaui, Brasil, with a possible date of 7,230 BP. The types of Asian parasites identified could not have entered through the Bering strait since their life cycles include a terrestrial stage with a range of temperatures no less than $18-22$ degrees Celsius. These conditions could not be met in the cold environment of the Bering passage. Consequently, a maritime migration has been suggested during the early Holocene from Asia or northwest Africa (Gonçalvez de Araujo, 1987) such as proposed by Meggers (1998), to the Ecuadorian coast.

\section{Conclusions}

1. The extreme desert conditions of the Peru-Bolivia and Chilean border have provided a geographic isolation for the introduction and conservation of the genetic indicator HTLV-1. Although it is assumed that the introduction of HTLV- 1 into the region preceded dates obtained from recorded evidence, this type of study highlights the biological tests helpful in understanding the migrations from Asia to 
America as human paleo-Indian and archaic skeletal remains are difficult to find. This type of data analysis allows us to conjecture about the biological characteristics of the first American populations, arriving in America in the late Pleistocene, early Holocene.

2. The dated samples (400-1,400 AD) originate from local, contemporaneous populations who lived during a period when the Tiwanaku State exercised great religious, stylistic and economic influence over the Atacama oasis and Arica. This generated heavy traffic of peoples in the South, Central Andean region between southern Peru, southern Bolivia, northwestern Argentina and northern Chile, precise where actual HTLV-1 samples have been identified.

3. Up until now, the theory of the Bering Strait Crossing is considered the strongest theory to explain the populating of the Americas. Some studies, however, have stressed the role of maritime colonization as another possibility. The existence of insular populations in Japan and other nearby Asian territories with significant HTLV- 1 presence, opens a new line of evidence in favor of the transpacific contact hypothesis. We need to know whether the first migrants to America did carry the HTLV-1 virus and other biological factor (i.e. parasites) or these were introduced by migrations, possibly across the ocean, subsequent to the closure of the Bering Strait passage, at the end of the Pleistocene.

The high frequency of HTLV- 1 in the SW region of Japan is notable. Japanese studies have confirmed HTLV- 1 presence in the prehistoric peoples of Jomon (ancient, maritime occupation; with ceramics; prior to the peopling of America) beginning 10,000 years ago. The Jomon may have emigrated due to external, agrarian, demographic pressures. In addition, the chronological and stylistic correlations between Jomon and the Ecuadorian coast suggest the arrival of Jomon colonies of fishermen.

4. The presence of HTLV-1 in a pre-Hispanic sample support the hypothesis that the virus found in current native populations in the South Central Andes have been endemic for a long period of time. In so much as HTLV- 1 having entered America with African slavery under Colonial rule, it has already been proven with the archaeological data that HTLV- 1 reached the Andes, before the slavery migration, from an Asian locus, establishing common, «protomongoloid», genetic ancestors for both Japanese and Andeans.

5. Notwithstanding the previous points, the paleoepidemiological results discussed in this work should be taken as primary evidence that serves to direct attention to the limitations of using archaeological data to infer intra and intercontinental population migratory movements. The paleovirological study, as it has been carried by the JapaneseLatin American team in an interdisciplinary approach, opens new possibilities for the issue of «diverse origins of the first American settlers», including the Asian continental connection (terrestrial contact) and extra-continental connection (maritime contact).

\section{REFERENCES}

ARRIAZA, B., A. AUFDERHEIDE and I. MUÑOZ. Análisis 1993 antropológico físico de la inhumación de Acha-2. Acha-2 y los Orígenes del Poblamiento Humano en Arica. Edited by I. Muñoz; B. Arriaza y A. Aufderheide, pp. 47-62. Ediciones Universidad de Tarapacá. Arica.

FERREL, R., S. BARTON, F. ROTHHAMMER and W. 1982 SCHULL. The multinational Andean genetic and health program: IX gene frequencies serum proteins and erythrocycle enzymes in the Aymara of Chile. American Journal of Human Genetics 32: 92-102.

GONCALVEZ DE ARAUJO. Paleoepidemiologia da 1987 Ancilostomose. Tese apresentada ao Curso de Pos- Graduacao da, Escola Nacional de Saúde Pública, para obtencao do Grau de Doutor em Saúde Pública, Río de Janeiro.
HONG-CHUAN, Li, Toshinobu FIJUYOSHI, Hong LOU,Shinji 1998a ms. YASHIKI, Shunro SONODA, Luis CARTIER, Lautaro NUÑEZ, Iván MUÑOZ, Satoshi HORAI and Kasuo TAJIMA. Ancient HTLV-1 provirus DNA of Andean mummies. Manuscript in possession of the authors.

HONG-CHUAN, Li; Toshinobu FIJUYOSHI, Hong LOU, 1998b ms. Shinji YASHIKI. Shunro SONODA, Luis CARTIER, Lautaro NUÑEZ, Iván MUÑOZ, Satoshi HORAI and Kasuo TAJIMA. Ancient HTLV-1 DNA from mummies of South American natives. Manuscript in possession of the authors.

IDO, E., M. YAMASHITA and M. HAYAMI. Ethnic variation 1996 of HTLV in the world. Ethnoepidemiology of Cancer, edited by Kazuo Tajima and Shunro Sonoda, pp. 107120.Tokyo: Japan Scientific Societies Press. 
IKEDA, M. and S. YOSHIDA. Epidemiology and cultural 1996 anthropology: Their possible collaboration. Ethnoepidemiology of Cancer, edited by Kazuo Tajima and Shunro Sonoda, pp. 7986. Tokyo: Japan Scientific Societies Press.

MEGGERS, B. J. Valdivia similarities: convergence or 1998 contact? Across Before Columbus? Evidence for Transoceanie Contact with the Americas Prior to 1492, edited by D. Y. Gilmore \& L. S. McElroy, pp. 11-21. Maine: Edgecomb.

NÚÑEZ, L. and T.D. DILLEHAY. Movilidad Giratoria, Ar1978 monía Social y Desarrollo en los Andes Meridionales: Patrones de Tráfico e Interacción Económica. Universidad del Norte, Antofagasta.

OAKLAND-RODMAN, A. Textiles and ethnicity: 1992 Tiwanaku in San Pedro de Atacama, north Chile. Latin American Antiquity 4:316340.
SARICH, V.M., C.W. SCHMID and J. MARKS. DNA 1989 hibridization as a guide to phylogenies: a critical analysis. Cladistics 5: 3-3 2.

TAJIMA, K. HTLV-1/II related disease with special 1996 reference to its distribution among Mongoloids. Gann Monograph on Cander Research 44: 123-135.

TAJIMA, K. Worldwide distribution of HTLV. 1998 Japanese Journal of Cancer Research Vol. 98(1).

TÉLLEZ, F. Rescate arqueológico de un cementerio en 1997 el patio de la casa parroquial (San Pedro de Atacama). Manuscript in possession of the author.

VELOSO M., A, and E. BUSTOS O., Eds. El Ambiente Natu1982 ral y las Poblaciones Humanas de los Andes del norte Grande de Chile (Arica Lat. 18" 28' S.), Volume 1 and 2. Santiago: MAB-6, UNESCO. 
